\title{
PENGARUH MODEL PEMBELAJARAN INKUIRI TERHADAP KEMAMPUAN PEMAHAMAN KONSEP DITINJAU DARI MOTIVASI BELAJAR SISWA
}

\author{
Ketren Ocmita Yanda ${ }^{1}$, Jumroh ${ }^{2}$, Dina Octaria ${ }^{3}$ \\ Universitas PGRI Palembang ${ }^{1,2,3}$ \\ dinaoktaria@gmail.com ${ }^{3}$
}

\begin{abstract}
ABSTRAK
Penelitian ini bertujuan untuk mengetahui ada atau tidaknya pengaruh model pembelajaran inkuiri terhadap kemampuan pemahaman konsep ditinjau dari motivasi belajar siswa. Metode penelitian yang digunakan adalah desain faktorial $2 \times 3$. Populasi pada penelitian ini adalah seluruh siswa kelas VIII SMP Shailendra Palembang. Teknik pengambilan sampel menggunakan teknik cluster random sampling. Sampel terpilih adalah siswa kelas VIII.1 dan siswa kelas VIII.2. Teknik pengumpulan data menggunakan angket dan tes. Analisis data menggunakan uji Analisis Varians dua jalur. Hasil dari penelitian ini adalah (1) Terdapat pengaruh model pembelajaran inkuiri terhadap kemampuan pemahaman konsep siswa kelas VIII SMP Shailendra Palembang, (2) Terdapat perbedaan antara kemampuan pemahaman konsep siswa ditinjau dari motivasi belajar (tinggi, sedang, rendah) siswa di SMP Shailendra Palembang, dan (3) Terdapat interaksi antara model pembelajaran (inkuiri dan konvensional) dan motivasi belajar siswa terhadap kemampuan pemahaman konsep siswa di SMP Shailendra Palembang
\end{abstract}

Kata kunci : inkuiri, pemahaman konsep, motivasi belajar

\begin{abstract}
This study aims to determine whether or not the influence of inquiry learning models on the ability to understand concepts in terms of student motivation. The research method used is a $2 \times 3$ factorial design. The population in this study were all students of class VIII SMP Shailendra Palembang. The sampling technique uses cluster random sampling technique. The selected sample is students in class VIII.1 and students in class VIII.2. Data collection techniques using questionnaires and tests. Data analysis uses the two-way Analysis of Variance test. The results of this study are (1) There is an influence of Inquiry learning model on the ability of students' understanding of concept VIII Shailendra Palembang Junior High School, (2) There is a difference between the ability to understand students' concepts in terms of learning motivation (high, medium, low) students at Shailendra Palembang Junior High School, and (3) There is an interaction between learning models (inquiry and conventional) and students' learning motivation towards students' concept understanding abilities at Shailendra Junior High School Palembang.
\end{abstract}

Keywords : inquiry, concept comprehension, learning motivation 


\section{PENDAHULUAN}

Pendidikan mempunyai peranan penting dalam mencerdaskan kehidupan bangsa dan negara. Sesuai dengan UUD Nomor 20 Tahun 2003 yang menyatakan bahwa tujuan pendidikan nasional adalah untuk mencetak generasi bangsa yang beriman dan bertakwa terhadap Tuhan Yang Maha Esa dan berbudi pekerti luhur, memiliki pengetahuan dan keterampilan, cerdas, kreatif.

Untuk mencapai tujuan pendidikan maka diperlukan seperangkat kurikulum yang menunjang, untuk diberikan kepada peserta didik dalam tingkatan satuan pendidikannya. Kurikulum merupakan jembatan untuk menuju tujuan pada tiap satuan pendidikan untuk beberapa mata pelajaran di sekolah. Satu diantaranya yaitu mata pelajaran yang ada mulai dari tingkat dasar sampai dengan tingkat perguruan tinggi adalah pelajaran matematika.

Matematika merupakan pelajaran yang memerlukan pemusatan pemikiran untuk mengingat dan mengenal kembali materi yang dipelajari sehingga peserta didik harus mampu menguasai konsep materi tersebut. Keberhasilan penguasaan konsep awal matematika pada peserta didik menjadi pembuka jalan dalam penyampaian konsep-konsep matematika pada materi selanjutnya (Hadi dan Kasum, 2015).

Menurut Masitoh dan Prabawanto (2015) pemahaman konsep merupakan dasar dan tahapan penting dalam rangkaian pembelajaran matematika. Penekanan utama pembelajaran matematika adalah bagaimana agar peserta didik mengerti konsepkonsep matematika dengan lebih baik. Agar peserta didik mampu memahami konsep matematika, maka pembelajaran matematika harus mampu memberikan kesempatan kepada peserta didik untuk mengkonstruksi konsep matematika, sehingga peserta didik tidak hanya diberi materi matematika abstrak yang membuat peserta didik sulit untuk memahami pelajaran matematika. Menurut Pranata (2016 : 37) pemahaman konsep adalah proses, perbuatan, cara memahami ide-ide materi pembelajaran, dimana peserta didik tidak sekedar mengenal dan mengetahui, tetapi mampu mengungkapkan kembali konsep yang lebih mudah dimengerti serta mampu mengaplikasikannya. Menurut NCTM (Kesumawati, 2010), untuk mencapai pemahaman yang bermakna maka pembelajaran matematika harus diarahkan pada pengembangan kemampuan koneksi matematik antar berbagai ide, memahami bagaimana ide-ide matematik saling terkait satu sama lain sehingga terbangun pemahaman menyeluruh, dan menggunakan matematik dalam konteks di luar matematika. Berdasarkan uraian tersebut pemahaman konsep merupakan suatu proses yang penting bagi setiap peserta didik untuk memahami dan mengaplikasikan materi yang dipelajari.

Proses pembelajaran yang terjadi biasanya di sekolah yaitu peserta didik diarahkan untuk menghapal dan mengingat informasi dan jarang diikutsertakan dalam berpikir, artinya proses pembelajaran hanya didominasi oleh guru (Rini, 2016 : 21). Hal tersebut dapat mengakibatkan kurangnya pemahaman konsep. Berdasarkan uraian tersebut pemahaman konsep merupakan suatu proses yang penting bagi setiap peserta didik untuk memahami dan mengaplikasikan materi yang dipelajari.

Keberhasilan seorang siswa dalam belajar juga dipengaruhi oleh adanya faktor psikis yang ada dalam dirinya. Faktor psikis akan menimbulkan keinginan, dorongan dan semangat belajar, atau menggerakkan siswa untuk lebih giat belajar, faktor psikis ini antara lain adalah motivasi belajar. 
Motivasi adalah suatu daya, dorongan atau kekuatan baik yang datang dari diri sendiri maupun dari luar yang mendorong siswa untuk belajar (Lestari dan Yudhanegara, 2017 : 93). Seseorang yang memiliki motivasi belajar akan mendorong mereka memahami dan menerapkan apa yang telah dipelajari. Menurut Annajmi (2016 : 2) guru adalah motivator dan menjadi contoh bagi siswa, apa yang dilakukan oleh guru akan ditiru oleh siswa. Oleh karena itu guru haruslah profesional di bidangnya. Guru profesional harus menguasai bahan mata pelajaran dan kurikulum serta mengenal dan dapat menggunakan model belajar untuk memaksimalkan hasil belajar siswa.

Salah satu cara untuk membantu siswa memahami konsep-konsep matematika sekaligus membangkitkan motivasinya yaitu dengan menerapkan model pembelajaran inkuiri. Menurut Sanjaya (Djuanda dan Maulana, 2015 : 46) model pembelajaran inkuiri merupakan rangkaian kegiatan pembelajaran yang menekankan pada proses berpikir kritis dan analitis untuk mencari dan menemukan sendiri jawaban dari suatu masalah yang dipertanyakan. Sedangkan menurut Israwani (2015 : 57) model pembelajaran inkuiri melatih siswa untuk berpikir secara kritis dan analisis, sehinga mampu memahami suatu konsep atau materi dengan baik dan rinci namun tetap mengedepankan sikap saling menghargai pendapat.

Adapun tahapan dalam model pembelajaran inkuiri (Majid, 2013), yaitu: 1) Orientasi, tahap ini adalah dimana siswa diajak untuk berpikir dan memecahkan masalah, 2) Merumuskan masalah, tahap ini adalah tahap dimana siswa mencari dan memecahkan sendiri jawabannya, 3) Merumuskan hipotesis, tahap ini adalah siswa menyampaikan penemuan atas permasalahan yang diberikan, 4) Mengumpulkan data, tahap dimana siswa mengumpulkan informasi yang didapat dari temuannya, 5) Menguji hipotesis, tahap ini adalah dimana siswa menguji hasil temuannya, dan 6) Merumuskan kesimpulan, dimana siswa menyimpulkan informasi yang didapat. Melalui tahapan model pembelajaran inkuiri dapat diciptakan suatu pembelajaran yang memungkinkan siswa mendapat kebebasan dalam mengajukan ide-ide, pertanyaan-pertanyaan dan masalah-masalah sehingga belajar matematika lebih efektif dan bermakna.

Menurut Daryanto (2010) model pembelajaran inkuiri menekankan kepada pengembangan aspek kognitif, afektif, dan psikomotorik secara seimbang. Dengan gaya belajar mereka serta dapat melayani kebutuhan peserta didik yang memiliki kemampuan di atas rata-rata. Hal ini sejalan dengan pendapat Pratiwi, dkk (2017 : 293) kelebihan-kelebihan yang terdapat pada model inkuiri, yaitu pembelajaran menjadi bermakna dan bisa melekat dalam pikiran siswa karena siswa diberikan kesempatan untuk melakukan, mencoba, dan mengalami sendiri dan bahkan tidak hanya sekedar menjadi pendengar yang pasif, serta guru tidak hanya mentransfer pengetahuan kepada siswa, tetapi siswa juga ikut terlibat langsung dalam proses pembelajaran. Hal ini didukung dengan penelitian yang sebelumnya dilakukan oleh Warmi (2016), yang menyatakan bahwa pembelajaran dengan menggunakan model inkuiri lebih baik daripada model pembelajaran langsung

Berdasarkan uraian tersebut maka penelitian ini bertujuan untuk mengetahui apakah ada pengaruh positif model pembelajaran inkuiri terhadap kemampuan pemahaman konsep siswa kelas VIII SMP Shailendra Palembang ditinjau dari motivasi belajar siswa. 


\section{METODE}

Metode yang digunakan dalam penelitian ini adalah factorial design yang merupakan modifikasi dari desain true experimental yaitu dengan memperhatikan kemungkinan adanya variabel moderator yang mempengaruhi perlakuan (variabel independen) terhadap hasil (variabel dependen). Dalam desain faktorial, variabel eksperimen dan variabel atribut dibagi atas beberapa level. Level yang digunakan dalam penelitian ini adalah desain faktorial $2 \times 3$, sebagai berikut :

Tabel 1. Desain faktorial $2 \times 3$

\begin{tabular}{ccc}
\hline \multirow{2}{*}{ Motivasi belajar siswa $\left(\mathrm{B}_{\mathrm{j}}\right)$} & \multicolumn{2}{c}{ Model pembelajaran $\left(\mathrm{A}_{\mathrm{i}}\right)$} \\
\cline { 2 - 3 } & Inkuiri $\left(\mathrm{A}_{1}\right)$ & Konvensional $\left(\mathrm{A}_{2}\right)$ \\
\hline Tinggi $\left(\mathrm{B}_{1}\right)$ & $\left(\mathrm{A}_{1} \mathrm{~B}_{1}\right)$ & $\left(\mathrm{A}_{2} \mathrm{~B}_{1}\right)$ \\
Sedang $\left(\mathrm{B}_{2}\right)$ & $\left(\mathrm{A}_{1} \mathrm{~B}_{2}\right)$ & $\left(\mathrm{A}_{2} \mathrm{~B}_{2}\right)$ \\
Rendah $\left(\mathrm{B}_{3}\right)$ & $\left(\mathrm{A}_{1} \mathrm{~B}_{3}\right)$ & $\left(\mathrm{A}_{2} \mathrm{~B}_{3}\right)$ \\
\hline & & Sugiyono $(2016)$
\end{tabular}

Keterangan :

$\mathrm{A}_{\mathrm{i}} \quad$ : Model pembelajaran

$B_{j} \quad$ : Motivasi belajar siswa

$\mathrm{A}_{1} \quad$ : Model pembelajaran Inkuiri

$\mathrm{A}_{2} \quad$ : Model pembelajaran konvensional

$\mathrm{B}_{1} \quad$ : Motivasi belajar tinggi

$\mathrm{B}_{2} \quad$ : Motivasi belajar sedang

$\mathrm{B}_{3} \quad$ : Motivasi belajar rendah

$A_{1} B_{1}$ : Motivasi belajar siswa tinggi melalui model pembelajaran Inkuiri

$A_{1} B_{2}$ : Motivasi belajar siswa sedang melalui model pembelajaran Inkuiri

$A_{1} B_{3} \quad$ : Motivasi belajar siswa rendah melalui model pembelajaran Inkuiri

$A_{2} B_{1}$ : Motivasi belajar siswa tinggi melalui model pembelajaran konvensional

$A_{2} B_{2}$ : Motivasi belajar siswa sedang melalui model pembelajaran konvensional

$\mathrm{A}_{2} \mathrm{~B}_{3} \quad$ : Motivasi belajar siswa rendah melalui model pembelajaran konvensional

Populasi dalam penelitian ini adalah seluruh siswa kelas VIII SMP Shailendra Palembang tahun ajaran 2019/2020 yang berjumlah 69 Siswa. Pengambilan data sampel menggunakan teknik cluster random sampling. Sampel terpilih adalah siswa kelas VIII.1 dan siswa kelas VIII.2.

Teknik pengumpulan data menggunakan angket dan tes. Angket untuk mengukur motivasi belajar siswa dan tes uraian untuk mengukur kemampuan pemahaman konsep siswa. Agar kualitas instrumen angket dan tes baik dan dapat mengukur sikap/kemampuan yang diinginkan, maka sebelum instrumen diberikan pada kelas eksperimen dan kelas kontrol, terlebih dahulu dibuat kisi-kisi angket dan tes sesuai dengan indikator, dibuat butir pernyataan angket dan tes sesuai dengan kisi-kisi, dan dilakukan validasi kepada validator. Sebelum tes diberikan kepada sampel penelitian, terlebih dahulu dilakukan ujicoba untuk menguji validitas, reliabilitas, daya pembeda, dan tingkat kesukaran.

Teknik analisis data yang digunakan uji Anova Dua Jalur. Uji Anova dua jalur yang digunakan untuk menganalisis dua gugus dengan mengikutsertakan variabel kontrol. Uji Anova dua jalur merupakan pengujian perbedaan rata-rata hasil pengukuran terhadap satu variabel dependen tetapi kriteria pengukuran lebih dari satu faktor. 


\section{HASIL DAN PEMBAHASAN}

Motivasi belajar siswa dilihat dari angket yang diberikan dan dijawab oleh siswa. Angket tersebut diberikan pada awal pertemuan. Angket motivasi belajar bertujuan untuk mengetahui tingkat motivasi belajar yang dimiliki siswa pada kelas eksperimen dan kelas kontrol. Angket yang diberikan adalah angket skala likert yang berisi pertanyaan positif dan negatif berjumlah 25 butir pernyataan. Setelah diperoleh data angket, kemudian motivasi belajar siswa dikelompokkan menjadi tiga, yaitu motivasi belajar tinggi, motivasi belajar sedang, dan motivasi belajar rendah.

Tabel 2. Pembagian tingkatan motivasi

\begin{tabular}{cccc}
\hline Kriteria tingkatan & \multicolumn{2}{c}{ Banyak siswa } & Jumlah \\
\cline { 2 - 3 } motivasi & Inkuiri & Konvensional & 18 \\
Tinggi & 13 & 5 & 37 \\
Sedang & 16 & 21 & 14 \\
Rendah & 5 & 9 & 69 \\
\hline & 34 & 35 & \\
\hline
\end{tabular}

Selanjutnya dilaksanakan pembelajaran pada masing-masing kelas. Pembelajaran inkuiri dilaksanakan pada kelas eksperimen dan pembelajaran konvensional dilaksanakan pada kelas kontrol.

Pada proses pembelajaran siswa pada kelas eksperimen diberikan Lembar Kerja Siswa (LKS) yang dikerjakan secara berkelompok, dimana dalam LKS diberikan soal dengan kemampuan pemahaman konsep dan langkah-langkah pengerjaan sesuai dengan model pembelajaran inkuiri. Pada langkah orientasi, siswa cukup mudah dalam memahami masalah yang diberikan dengan bimbingan yang diberikan melalui setiap langkah-langkah yang terdapat pada LKS, sehingga siswa mampu menentukan kecukupan unsur-unsur yang diketahui dari permasalahan yang diberikan dan mampu merumuskan model matematika dari permasalahan yang ada pada LKS. Pada langkah merumuskan masalah dan merumuskan hipotesis, siswa cukup sistematis dalam menentukan penyelesaian dari permasalahan yang ada melalui langkah-langkah penyelesaian yang terdapat pada LKS sehingga siswa cukup mudah dalam menyelesaikan permasalahan tersebut. Sedangkan pada langkah mengumpulkan data, menguji hipotesis dan merumuskan kesimpulan masih ada beberapa siswa yang bingung dalam menerapkan rumus dan siswa cenderung kurang teliti dalam memeriksa kembali kebenaran jawaban (menyimpulkan) pada permasalahan yang diberikan.

Setelah mendapatkan pembelajaran inkuiri, siswa sudah terbiasa dalam memahami bagaimana cara menjawab soal matematis dan akan terasa lebih mudah, karena konsep atau rumus yang didapat berdasarkan hasil dari pikiran mereka sendiri. Sehingga konsep yang didapat akan lebih lama diserap dalam memori siswa, bukan dari penjelasan guru yang membuat siswa akan cepat lupa. Hal ini karena pada pembelajaran inkuiri siswa dilatih untuk berpikir mandiri dalam menentukan, menemukan dan mendapatkan kembali rumus atau prosedur yang ada pada umumnya, yang terdapat pada tahap merumuskan masalah. Sehingga pada tahap merumuskan hipotesis siswa sudah terbiasa dalam memahami bagaimana cara menjawab soal matematis dan akan terasa lebih mudah. Dengan demikian dapat dikatakan bahwa model pembelajaran inkuiri ini dapat dijadikan sebagai salah satu 
model pembelajaran yang dapat meningkatkan kemampuan pemahaman konsep matematis siswa.

Pada kelas kontrol, siswa hanya menerima penjelasan guru. Siswa tidak diajak untuk mencari penyelesaian secara mandiri, tapi cenderung didominasi guru, sehingga siswa terbiasa menunggu arahan dan penyelesaian dari guru. Memang terkadang guru memberi kesempatan pada siswa untuk melakukan penyelidikan terhadap masalah yang ada pada materi, namun hal itu tidak sepenuhnya dilakukan siswa, masih guru juga yang cenderung mengambil-alih penyelesaiannya. Tentunya akan berakibat pada hasil akhir yang diperoleh siswa.

Tabel 3. Rata-rata nilai tes kemampuan pemahaman konsep matematis siswa setiap pertemuan

\begin{tabular}{lccc}
\hline \multirow{2}{*}{ Kelas } & \multicolumn{3}{c}{ Pertemuan } \\
\cline { 2 - 4 } & 1 & 2 & 3 \\
\hline Eksperimen & 58,2 & 67,9 & 77,5 \\
Kontrol & 55.2 & 64 & 69.8 \\
\hline
\end{tabular}

Berdasarkan tabel 3 di atas menunjukkan nilai rata-rata siswa setiap pertemuannya lebih meningkat dari sebelumnya. Dapat dilihat juga bahwa nilai pada kelas eksperimen lebih baik dibandingkan nilai pada kelas kontrol.

Setelah pembelajaran berakhir pada masing-masing kelas, diberikan tes kemampuan pemahaman konsep. Rata-rata nilai hasil tes tersebut sebagai berikut:

Tabel 4. Rekapitulasi hasil tes kemampuan pemahaman konsep matematis siswa berdasarkan pengelompokan motivasi belajar

\begin{tabular}{|c|c|c|c|c|}
\hline \multirow{3}{*}{$\begin{array}{c}\text { Motivasi } \\
\text { belajar }\end{array}$} & \multirow{3}{*}{ Statistik } & Kemampua & ahaman konsep & \multirow{3}{*}{ Jumlah } \\
\hline & & \multicolumn{2}{|c|}{ Pembelajaran } & \\
\hline & & Inkuiri & Konvensional & \\
\hline \multirow{2}{*}{ Tinggi } & $N$ & 13 & 5 & 18 \\
\hline & $\bar{x}$ & 83.3 & 62.5 & 72.9 \\
\hline \multirow{2}{*}{ Sedang } & $N$ & 16 & 21 & 37 \\
\hline & $\bar{x}$ & 75 & 75 & 75 \\
\hline \multirow{4}{*}{ Rendah } & $N$ & 5 & 9 & 14 \\
\hline & $\bar{x}$ & 63.4 & 62.5 & 62.9 \\
\hline & $N$ & 34 & 35 & 69 \\
\hline & Rata-rata & 73.9 & 66.6 & 70.25 \\
\hline
\end{tabular}

Berdasarkan tabel 4 di atas dapat dilihat ada perbedaan pemahaman konsep matematis antara siswa yang memiliki motivasi belajar tinggi, sedang, dan rendah pada kelas eksperimen dan kelas kontrol. Motivasi belajar seorang siswa akan sangat menentukan tingkat pencapaian prestasi belajarnya (Susanti 2015 : 154). Apabila motivasi belajar siswa tinggi, tentunya hasil belajarnya pun tinggi, dan sebaliknya. Pada penelitian yang dilakukan Rosyadi (2016) juga menunjukkan bahwa semakin tinggi motivasi belajar siswa maka semakin tinggi pula hasil belajar matematika.

Selanjutnya dilakukan analisis data dengan menggunakan uji Anova Dua Jalur. Sebelumnya dilakukan terlebih dahulu uji prasyarat yaitu uji normalitas dan uji homogenitas untuk mengetahui apakah data yang dianalisis normal dan homogen. 
Semua teknik analisis data dalam penelitian ini menggunakan program SPSS 22 For Windows.

Uji normalitas dalam penelitian ini menggunakan Uji Kolmogorov-Smirnov. Berdasarkan hasil postes diperoleh nilai signifikan untuk kelas eksperimen adalah $0.072>(\propto=0,05)$ dan signifikan untuk kelas kontrol adalah $0.069>(\propto=0,05)$ sehingga dapat disimpulkan bahwa data yang diambil dari populasi yaitu berdistribusi normal. Uji homogenitas data menggunakan uji Levene Statistik. Berdasarkan hasil perhitungan diperoleh nilai signifikansi $0,058>(\propto=0,05)$, sehingga dapat disimpulkan bahwa varians nilai tes dari dua kelas adalah sama (homogen). Selanjutnya dilakukan pengujian hipotesis dengan menggunakan uji anova dua jalur, hasilnya dapat dilihat pada tabel 5 berikut ini.

Tabel 5. Uji anova dua jalur

Tests of Between-Subjects Effects

Dependent Variable: kemampuan pemahaman konsep

\begin{tabular}{|l|r|r|r|r|r|}
\hline Source & $\begin{array}{c}\text { Type III Sum of } \\
\text { Squares }\end{array}$ & Df & Mean Square & \multicolumn{1}{|c|}{ F } & Sig. \\
\hline Corrected & $7450.123^{\mathrm{a}}$ & 4 & 1862.531 & 46.138 & .000 \\
Model & 157336.776 & 1 & 157336.776 & 3897.493 & .000 \\
Intercept & 216.670 & 1 & 216.670 & 5.367 & .024 \\
MP & 5953.512 & 2 & 2976.756 & 73.739 & .000 \\
MB & 256.197 & 1 & 256.197 & 6.346 & .014 \\
MP * MB & 2583.597 & 64 & 40.369 & & \\
Error & 385838.080 & 69 & & & \\
Total & 10033.720 & 68 & & & \\
Corrected & & & & \\
Total & & & & \\
\hline
\end{tabular}

a. R Squared $=.743$ (Adjusted R Squared $=.726$ )

Berdasarkan pada tabel 5 diperoleh :

1. Nilai signifikan $=0,024<0,05$, sehingga $\mathrm{H}_{0}$ ditolak, dengan demikian terdapat pengaruh yang signifikan model pembelajaran inkuiri terhadap kemampuan pemahaman konsep matematis siswa kelas VIII SMP Shailendra Palembang.

2. Nilai signifikan $=0,000<0,05$, sehingga $\mathrm{H}_{0}$ ditolak, dengan demikian terdapat perbedaan yang siginifikan antara kemampuan pemahaman konsep matematis siswa ditinjau dari motivasi belajar siswa kelas VIII SMP Shailendra Palembang.

3. Nilai signifikan $=0,014<0,05$, sehingga $\mathrm{H}_{0}$ ditolak, dengan demikian terdapat interaksi antara model pembelajaran inkuiri dan motivasi belajar siswa terhadap kemampuan pemahaman konsep matematis siswa kelas VIII SMP Shailendra Palembang

Hasil uji anova ini menunjukkan bahwa penerapan model pembelajaran inkuiri berpengaruh terhadap kemampuan pemahaman konsep matematis siswa. Juga motivasi belajar siswa menentukan kemampuan pemahaman konsep matematis siswa. Hal ini sependapat dengan penelitian yang dilakukan oleh Setiawan, dkk (2019) yang telah melakukan penelitian tentang "Pengaruh Model Pembelajaran 
Inkuiri Terbimbing Terhadap Pemahaman Konsep Fisika Ditinjau dari Motivasi Belajar Siswa". Hasil penelitiannya menunjukkan ada perbedaan pemahaman konsep fisika, antara yang memiliki motivasi belajar tinggi dengan siswa yang memiliki motivasi belajar rendah pada kelas eksperimen dan kelas kontrol.

Kemudian terdapat interaksi antara model pembelajaran inkuiri dan motivasi belajar siswa terhadap kemampuan pemahaman konsep matematis siswa kelas VIII SMP Shailendra Palembang. Interaksi menunjukkan pola tiap faktor yang diuji berbeda. Pola berbeda ini akan lebih mudah dipahami dengan melihat adanya persilangan garis pada grafik. Hasil ini sesuai temuan pada penelitian sebelumnya oleh Rini (2016) dengan penelitian "Pemahaman Konsep dan Motivasi Belajar Matematika Siswa Kelas X Madrasah Aliyah Negeri 1 Palu Melalui Model Pembelajaran Berbasis Masalah dan Model Pembelajaran Inkuiri", hasil penelitiannya menunjukkan ada interaksi antara model pembelajaran dan motivasi belajar terhadap pemahaman konsep matematika siswa. Juga sejalan dengan penelitian Marliyah (2019) yang berjudul "Pengaruh Penggunaan Model Inquiry Learning dan Discovery Learning Terhadap Prestasi Belajar IPA Siswa Kelas VI SD Ditinjau dari Motivasi Belajar", hasil penelitiannya menunjukkan ada interaksi antara penggunaan model pembelajaran inquiry learning dan discovery learning dengan motivasi belajar siswa terhadap prestasi belajar IPA.

Untuk mengetahui tingkat kemampuan pemahaman konsep matematis siswa berdasarkan indikator kemampuan pemahaman konsep, berikut ini ditampilkan perbandingan rata-rata skor kemampuan pemahaman konsep siswa tiap-tiap indikator pada kelas eksperimen dan kelas kontrol.

Tabel 6. Rata-rata skor tes kemampuan pemahaman konsep matematis siswa perindikator

\begin{tabular}{|c|c|c|c|}
\hline No. & Indikator & $\begin{array}{c}\text { Kelas } \\
\text { eksperimen }\end{array}$ & $\begin{array}{c}\text { Kelas } \\
\text { kontrol }\end{array}$ \\
\hline 1 & Menyatakan ulang sebuah konsep & 81,5 & 68.1 \\
\hline 2 & $\begin{array}{l}\text { Mengklasifikasiklan objek-objek menurut } \\
\text { sifat-sifat tertentu (sesuai dengan konsepnya) }\end{array}$ & 75 & 69 \\
\hline 3 & $\begin{array}{l}\text { Memberikan contoh dan non-contoh dari } \\
\text { konsep }\end{array}$ & 72 & 64 \\
\hline 4 & $\begin{array}{l}\text { Menyajikan konsep dalam berbagai bentuk } \\
\text { representasi matematis }\end{array}$ & 73 & 67 \\
\hline 5 & $\begin{array}{l}\text { Mengembangkan syarat perlu atau syarat } \\
\text { cukup suatu konsep }\end{array}$ & 69 & 63 \\
\hline 6 & $\begin{array}{l}\text { Menggunakan, memanfaatkan, dan memilih } \\
\text { prosedur atau operasi tertentu }\end{array}$ & 73 & 64.1 \\
\hline 7 & $\begin{array}{l}\text { Mengaplikasikan konsep atau algoritma } \\
\text { pemecahan masalah }\end{array}$ & 74 & 71 \\
\hline & Rata-rata & 73,9 & 66,6 \\
\hline
\end{tabular}

Berdasarkan tabel 6 di atas rata-rata nilai tes akhir kemampuan pemahaman konsep kelas eksperimen yaitu 73,9 dan untuk kelas kontrol yaitu 66,6. Untuk kelas eksperimen, nilai tertinggi yaitu pada indikator menyatakan ulang sebuah konsep yang meliputi kemampuan siswa untuk mengungkapkan kembali apa yang telah dikomunikasikan kepadanya dan mampu menyatakan ulang maksud dari pernyataan itu, dan nilai terendah yaitu mengembangkan syarat perlu atau syarat cukup suatu konsep yang meliputi siswa dapat memahami suatu materi dengan melihat syarat- 
syarat yang harus diperlukan dan yang tidak diperlukan. Untuk kelas kontrol, nilai tertinggi yaitu pada indikator mengaplikasikan konsep atau algoritma pemecahan masalah, dan nilai terendah yaitu mengembangkan syarat perlu atau syarat cukup suatu konsep yang meliputi siswa dapat memahami suatu materi dengan melihat syarat-syarat yang harus diperlukan dan yang tidak diperlukan.

Gambaran kemampuan mengembangkan syarat perlu atau syarat cukup suatu konsep ini dapat dilihat dari salah satu jawaban siswa pada gambar 1 berikut ini.
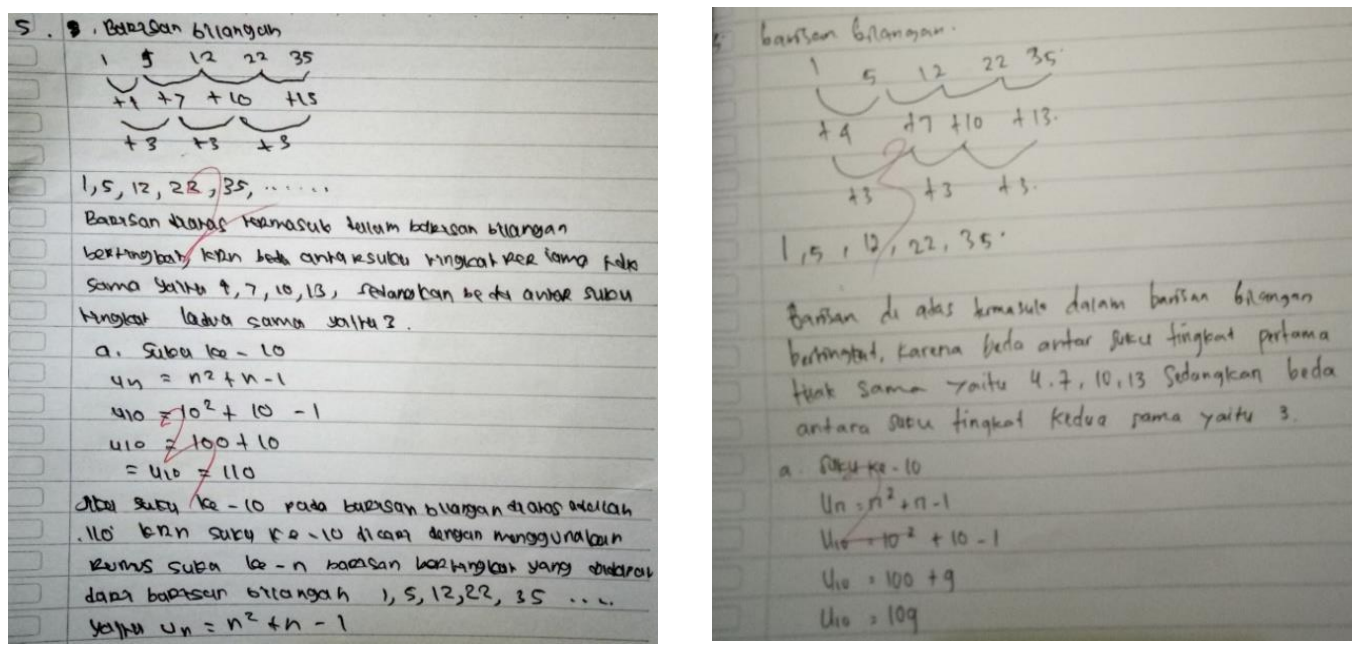

Gambar 1. Hasil jawaban siswa kelas eksperimen (kiri) dan kelas kontrol (kanan)

Pada gambar 1 terlihat bahwa pada jawaban siswa kelas eksperimen cukup baik dalam menerapkan syarat perlu suatu konsep dan menerapkan rumus sehingga teliti dalam memeriksa kebenaran jawaban (menyimpulkan). Sedangkan pada kelas kontrol, penerapan rumus cukup baik akan tetapi siswa tidak memeriksa kembali kebenaran jawaban (menyimpulkan) pada permasalahan yang diberikan.

\section{SIMPULAN}

Berdasarkan data hasil penelitian dan pembahasan, maka dapat disimpulkan sebagai berikut: (1) Terdapat pengaruh model pembelajaran inkuiri terhadap kemampuan pemahaman konsep matematis siswa kelas VIII SMP Shailendra Palembang, (2) Terdapat perbedaan antara kemampuan pemahaman konsep matematis siswa ditinjau dari motivasi belajar siswa di SMP Shailendra Palembang, dan (3) Terdapat interaksi antara model pembelajaran (inkuiridan konvensional) dan motivasi belajar siswa terhadap kemampuan pemahaman konsep matematis siswa di SMP Shailendra Palembang.

\section{DAFTAR PUSTAKA}

Annajmi. 2016. Peningkatan Kemampuan Pemahaman Konsep Matematika Siswa SMP Melalui Metode Penemuan Terbimbing Berbantuan Software Geogebra. Jurnal MES (Journal of Mathematics Education and Science), Vol. 2(1) : 1-10. Daryanto. 2010. Belajar dan Mengajar. Bandung: C.V. Yrama Widya.

Djuanda, D. dan Maulana. 2015. Ragam Model Pembelajaran di Sekolah Dasar. Sumedang: UPI Sumedang Press. 
Hadi, S. dan Kasum, M.U. 2015. Pemahaman Konsep Matematika Siswa SMP Melalui Penerapan Model Pembelajaran Kooperatif Tipe Memeriksa Berpasangan (Pair Checks). EDU-MAT .Jurnal Pendidikan Matematika, Vol. $3(1): 59-66$.

Israwani. 2015. Penggunaan Model Pembelajaran Inkuiri Pada Materi Operasi Hitung Bilangan di Kelas I SD Negeri 53 Banda Aceh. Jurnal Peluang, Vol. $3(2): 55-64$.

Kesumawati, Nila. 2010. Peningkatan Kemampuan Pemahaman, Pemecahan Masalah, dan Disposisi Matematis Siswa SMP Melalui Pendekatan Pendidikan Matematika Realistik. Disertasi tidak diterbitkan. Bandung: Universitas Pendidikan Indonesia.

Lestari, K. L. dan Yudhanegara, M. R. 2017. Penelitian Pendidikan Matematika. Bandung: Refika Aditama.

Majid, Abdul. 2013. Strategi Pembelajaran. Bandung: Remaja Rosdakarya.

Marliah, S., dkk. 2019. Pengaruh Penggunaan Model Inquiry Learning dan Discovery Learning Terhadap Prestasi Belajar IPA Siswa Kelas VI SD Ditinjau dari Motivasi Belajar. Jurnal Education and Development, Vol. 7(2) : 169-174.

Masitoh, I. dan Prabawanto, S. 2015. Peningkatan Pemahaman Konsep Matematika dan Kemampuan Berpikir Kritis Matematis Siswa Kelas V Sekolah Dasar Melalui Pembelajaran Eksploratif. EduHumaniora Jurnal Pendidikan Dasar, Vol. 7(2) : 1-11.

Pranata, Ella. 2016. Implementasi Model Pembelajaran Group Investigation (GI) Berbantuan Alat Peraga Untuk Meningkatkan Kemampuan Pemahaman Konsep Matematika. Jurnal Pendidikan Matematika Indonesia, Vol. 1(1) : 3438.

Pratiwi, C. O., dkk. 2017. Penerapan Model Pembelajaran Inkuiri Untuk Meningkatkan Hasil Belajar Siswa Kelas V Pada Materi Pesawat Sederhana. Jurnal Pena Ilmiah, Vol. 2(1) : 291-300.

Rini, E. S. 2016. Pemahaman Konsep dan Motivasi Belajar Matematika Siswa Kelas X Madrasah Aliyah Negeri 1 Palu Melalui Model Pembelajaran Berbasis Masalah dan Model Pembelajaran Inkuiri. e-Jurnal Mitra Sains, Vol. 4(2) : 20-29.

Rosyadi. 2016. Pengaruh Motivasi dan Kebiasaan Belajar Siswa Terhadap Hasil Belajar Matematika. Mathline : Jurnal Matematika dan Pendidikan Matematika, Vol. 1(2).

Setiawan. D. dkk. 2019. Pengaruh Model Pembelajaran Inkuiri Terbimbing Terhadap Pemahaman Konsep Fisika Ditinjau dari Motivasi Belajar Siswa. Makalah Pada Seminar Nasional Pendidikan FKIP Universitas Lambung Mangkurat, Banjarmasin, 23 Maret 2019. Hal: 45-53. ISBN: 978-602-6483-95-9.

Sugiyono. 2016. Metode Penelitian Pendidikan. Bandung: Alfabeta.

Susanti, A. 2015. Pengaruh Motivasi Belajar Siswa Terhadap Prestasi Belajar Matematika Siswa. Jurnal Pendidikan Matematika STKIP PGRI Sidoarjo, Vol. 3(2) : 151-158.

Warmi, Attin. 2016. Pengaruh Penggunaan Strategi Pembelajaran Inkuiri Terhadap Kemampuan Pemahaman Matematik Peserta Didik (Penelitian Terhadap Peserta Didik Kelas V SDN Paturahman Desa Sukaratu Kecamatan Wanaraja Kabupaten Garut Tahun Pelajaran 2013/2014. Jurnal Cakrawala Pendas, Vol. 2(1) : 70-82. 